\title{
Inflation Targeting and World Monetary Shocks: Evidence from Developing Economies
}

\author{
Noura Abu Asab \\ Department of Economics, School of Business, University of Jordan, Amman, Jordan \\ Email address: \\ n.abuasab@ju.edu.jo \\ To cite this article: \\ Noura Abu Asab. Inflation Targeting and World Monetary Shocks: Evidence from Developing Economies. International Journal of Business \\ and Economics Research. Vol. 9, No. 3, 2020, pp. 140-150. doi: 10.11648/j.ijber.20200903.17
}

Received: April 16, 2020; Accepted: May 3, 2020; Published: May 27, 2020

\begin{abstract}
The paper assesses the co-movement of local and foreign interest rate for developing countries with a full-fledged inflation targeting framework during and after the 2008 financial crisis. A panel linear optimizing monetary model is estimated by the fixed effects with spatial correlation standard errors over quarterly span from Q12007 to Q2 2019. The results suggest that inflation targeters are highly vulnerable to external monetary shocks, even after years of notable efforts to de-dollarization and complete shift towards a full-fledged inflation targeting. From a regime evaluation prospective, the inflation targeters' response to world monetary shocks is compared to that of a group of fixed exchange rate rule economies and managed exchange rate countries with other monetary regimes. The findings provide evidence that inflation targeting countries are not different in their interest rate response to world monetary shocks compared to non-inflation targeting countries', and instead of having more flexibility, inflation targeters show stronger reaction to world monetary shocks. These results are found robust when generated out from different subsamples and under assumptions of strict and flexible inflation targeting and policy inertia. The findings indicate that adopting inflation targeting as a framework for monetary policy does not by itself support the overall macroperformance and independence of monetary policy or force continuing commitment to the inflation targeting conditions.
\end{abstract}

Keywords: Inflation Targeting, Monetary Shocks, External Vulnerability, Interest Rate, Panel Data

\section{Introduction}

In the recent decades, Inflation Targeting (IT) has attracted much attention as a new promised monetary regime. Based on what monetary policy can do, the advantages of low inflation and the necessity of having a nominal anchor, many countries have developed the rationale for adopting IT. But why should we consider this a rational decision?

During the late $1960 \mathrm{~s}$ and $1970 \mathrm{~s}$, the world has experienced high and unstable inflation rates and the promises of activists to keep the output and the unemployment close to their full-employment levels have failed at all the time. Instead, many countries have encountered recessions as eradicating high inflation rates resulted in high social and economic costs [9]. The studies [24] and [47] provide evidence that the negative nexus between inflation and unemployment holds only in the short run and turns into a vertical one in the long-run, i.e. there is no long run trade-off between them due to the adjustments in inflation expectations. Hence, the monetary policy has neutral real effects in the long-run and the monetary policy should only focus on achieving price stability.

However, politicians may exploit the short run trade-off between inflation and unemployment, by cutting interest rates and overheating the economy regardless of the long run consequences. The inconsistency between the political short run horizons and the long run policy nexus would lead to disastrous outcomes. This means that expansionary policies have transitory effects and they indeed encounter time inconsistency problem (for more details see the studies [37] and [8]). This brings the need for a nominal anchor and what can be better than targeting the prices; the variable that the public mostly cares about and easily understands and observes.

Moreover, what distinguishes IT from other nominal anchors is its flexibility in dealing with the economic objectives. So instead of constraining monetary policy by the fixed exchange rate, IT is a "look at everything strategy albeit 
with a focused goal" [9], that is price stability. That is why IT should not be considered a strict monetary rule but rather a framework for monetary policy. This is because inflation targeters can react to unpredictable shocks in short-run but maintain a unique direction of achieving low inflation rate in the long run; the only goal the monetary policy can achieve. ${ }^{1}$

Therefore, the IT framework has evolved over time and become a popular choice among developed and developing countries under certain conditions for adopting the framework. The specific features (conditions) which are also called the preconditions for adopting a full-fledged IT include: ${ }^{2}$ the announcement of an explicit point or range inflation target; setting the price stability as the main and ultimate objective of monetary policy; achieving high degree of central bank independence, monetary policy transparency and accountability; and having a well-understood nexus between inflation and monetary instruments [51]. ${ }^{3}$ In addition, under IT the interest rate pass-through channel is the main monetary policy transmission channel.

IT comes along with flexible (free-floating) exchange rate regime and most emerging market ITers have abandoned anchors of limited exchange rate flexibility in favour of IT. Most economies have shifted to the corner of adopting IT with a float or join a monetary union [32]. Therefore, many authors have argued that pursuing a free floating exchange rate is a precondition for IT, because monetary policy cannot be independent while the exchange rate is fixed, as implied by the impossible trinity.

Literature has widely investigated the benefits of adopting IT. According to the study [44], IT countries have experienced less volatility in interest rate and their international reserves have become less responsive towards exchange rate (external) shocks. In addition, they found that ITers react less to shocks in oil prices and exchange rate movements.

Yet, the issue of independence and the response to world monetary shocks under IT, namely during and after the 2008 financial crisis, has not been dealt with in recent debates. Most authors have pointed out the IT worked well in developing countries, and it well-anchored inflation expectations which came along with the implementation of macro-prudential policies. Hence, it is not our purpose in this paper to re-evaluate the overall performance of the framework but to assess the monetary response, i.e. the response of the main monetary instrument, to world monetary shocks for developing countries under IT especially during the bad times and recovery times of the 2008 financial crisis and after years of adopting the full-fledged IT and macro prudential and dedollarization policies. From a regime evaluation prospective, we compare their response to a group

\footnotetext{
1 Many inflation targeters target the underlying inflation which excludes significant changes and movements in commodity and oil prices, terms of trade, government polices and other prices determined on an ad hoc basis [9].

2 However, there is lack of consensus among economists upon the set of conditions for the full-fledged IT.

3 Some inflation targeters like Canada and Australia do not officially announce price stability as their monetary policy's primary goal [10].
}

of fixed exchange rate rule economies and a managed exchange rate countries with other monetary regimes ${ }^{4}$

In fact, the countries which allow independent monetary policy should be less sensitive to foreign interest rates [23]. Therefore, the strong co-movement between local and foreign interest rates may show to how extent the monetary policy is independent and flexible.

Due to the above considerations, that is with dedollarization polices along with the conditions of IT, we should see that developing inflation targeters differ in their response to the world monetary shocks from any developing economies with discretionary or ruled based monetary policies. In another way we could raise the question: do ITers have more flexibility (less sensitivity) towards the world monetary policy shocks especially at time following years of notable efforts to de-dollarization and complete shift towards a full-fledged IT but at the same time during and after the financial crisis of 2008 .

The reminder of the paper is structured as follows. Section two discusses the advantages and shortcomings of IT. Section three presents the issue of de-dollarization. Section four and five display the data sources and methodology, respectively. Section six summarizes the results and section seven concludes.

\section{Inflation Targeting: The Preconditions, Advantages and Shortcomings}

Ultimately, the credibility of the framework hinges upon achieving the announced inflation target. In order to achieve the announced numerical target of a head or core inflation rate, IT has special institutional and operational characteristics or conditions. The full-fledged IT country should satisfy the preconditions for adopting the framework. However, when the country enjoys a credible monetary policy and targets price stability but does not adhere to all IT's rules it is classified as eclectic ITer [3]. On the other hand, if the country suffers from a fragile financial market and is exposed to foreign shocks, the IT is lite. Literature argues that profiting from IT can vary significantly from developed to developing countries and this can be attributed to their differences on fulfilling the preconditions for adopting the framework. ${ }^{5}$

Central banks under IT should enjoy a high degree of independence. According to many studies, for example, [18, $17,29,53]$ and [4] among others, the central bank independence is linked to low inflation. The independence comprises according to the study [42] the political independence that represents the personnel character of the bank; the economic (policy) independence which entails the policy formulation, objectives and tools of monetary policy; and the financial independence that involves placing

\footnotetext{
4 Note that this evaluation is not a comparison of the exchange rate selection but rather a regime comparison.

5 All countries that adopted IT enhanced their prerequisites after the adoption and not before but they were willing and ready to satisfy the conditions.
} 
restrictions on financing the government fiscal deficit and debt as fiscal deficit is an inflationary phenomenon (see [40]). Hence, central banks under IT should have institutional legislations combined with real deeds that allow them to achieve the target given that the monetary policy has neutral real effects in the long run.

The questions that might be raised, even in highly independent central banks in developed countries, is " how independent the central bank can be of the government that owns it and is able to tax it?" ([10], p18)

If the central bank is not personnel independent, the scenario that might prevail is that the central bank can be insolvent and attempt or be forced to print out money to avoid this. And the answer indeed relies on the willingness and ability of the government to commit itself not to deplete the central bank's own resources. i.e. this commitment depends on the same political factors that induce the mandate of monetary policy to an independent monetary authority [10]. This means that IT requires a strong coordination between the central bank and government with respect to monetary policy objectives and roles.

IT not only paves the way for central bank independence and collaborative economic policies, it is by all measures a regime to communicate with the public [45]. The monetary policy under IT is highly transparent as the announcement of an inflation target to the public allows the market agents to know the future course of inflation from an official source. Inflation targets influence inflation expectations directly and thus it reinforces credibility for the monetary policy [52]. This transparency reduces uncertainty and controls the market expectations, i.e. anchoring the inflation expectations [19].

In fact, high inflation leads to higher inflation uncertainty as hypothesized by the studies [25] and [6] and many authors support their hypothesis, e.g. [56] and [36]. Inflation uncertainty can even generate higher inflation rates as proposed by the study [16]. The high unpredictability of change in prices can also retard economic growth [35] [30]. Hence, IT eliminates the surprises that might result in inflation uncertainty [26], and thus lowering inflation uncertainty [17] and reducing the volatility of expected inflation [12]. As transparency of the framework anchors the expectations of people and eliminates uncertainty of inflation, the long-run effect of interest rate on consumption and investment decisions gets improved.

A large and growing body of literature has traced the development and success of IT and its impacts on macroeconomic factors. Particularly, the empirical findings provide a telling example on the regime successful story. The study [21] provides evidence that countries which adopted IT regime experienced a decrease in the pass-through from exchange rate to inflation. Similarly, the study [13] revealed that adopting inflation targeting reduces the degree of exchange rate pass-through. The study [44] showed that inflation under IT responds less to oil prices and exchange rates shocks. Additionally, the study [52] found that, for the case of Chile, the credibility and strength of monetary policy has developed with the achievement of stable inflation rates. Furthermore, the study [58] revealed that the performance of macroeconomic variables has improved in developing economies after adopting IT. Similarly, a research finding by the study [44] also pointed out that adopting IT in developing and developed economies boosted the macroeconomic performance. In contrast to the above findings, the study [7] claimed that IT has not made any difference for its adopters. According to the investigation by the study [50] fully-fledged inflation targeters missed achieving about 40 percent of their pronounced inflation targets of the time and this percent goes substantially higher for longer periods. The study [2] suggested that operational policy and institutional arrangements weaknesses, including low or lack of central bank independence and high country risk premia, explain why inflation targets are missed.

In addition, the study of [33] for the Czech Republic revealed that the country has experienced years of inflation targets undershooting and negative output gap for most of inflation targeting period and its exchange rate volatility has been the main challenge. However, they concluded that the country was successful at anchoring inflation expectations and disinflation polices and they claimed that IT has served well as a nominal anchor. Moreover, the study of [5] found that central bank independence is not linked to adopting IT in emerging market economies (countries with low independence) and what helped these countries in their efforts of lowering inflation rates was the reductions in budget deficits after the adoption. The study [29] found that dollarization imposes difference in the transmission effectiveness of monetary policy and the financial sectors, but it does not hinder using IT as a policy regime. The study of [15] documented the increase in exchange market interventions in Latin American ITers during and after the financial crisis. They even found that the real exchange rate has regularly become a monetary policy target. Nevertheless, despite the unsatisfactory outcomes of polices under IT in some aspects, no country has unwillingly opted out of the regime. ${ }^{6}$ However, far too little attention has been paid to the response of inflation targeters to world monetary shocks after years of hanging on the framework.

\section{Dollarization and De-dollarization Polices}

Most if not all developing countries adopting IT have executed market driven financial de-dollarization polices. The term dollarization is categorized by the World Bank under three groups: the first is the liability dollarization where the economy has relatively large debts denominated in foreign currency; the second one is the asset dollarization, in this case the country uses the foreign currency to serve as any functions of money; and finally the full or official dollarization in which an economy abandons its own

6 Here we point out to the case of Spain, Slovakia and Finland which shifted from IT to join the monetary union. 
currency in the favor of a foreign currency.

However, the term " financial dollarization" has recently emerged and embodies the assets and liability denominated in foreign currency held by residents and includes banks loans and deposits as well as non banks assets e.g. sovereign debt and this is the term we clarify here in the discussion. ${ }^{7}$ As a matter of fact, financial dollarization widespread in many developing countries, and it was the main factor behind systemic financial fragility in Latin America [22].

In fact, any external shocks may raise the debt burden of the economy namely with foreign linked debt. The appreciation of the dollar (foreign currency) - depreciating of domestic currency- may trigger financial solvency of business and financial institutions. As assets of business and financial firms are denominated in domestic currency, the depreciation of the exchange rate will be resulting in a sharp decline in net worth. This consequently increases adverse selection and moral hazard problems which lower investment and economic activities. The financial intermediaries sector gets affected by the systemic crisis through the currency risk in their balance sheet or credit risk of loans denominated in the US Dollar (foreign currency) [22]. Most developing countries that run financial deficits tend to finance these deficits by having dollar-denominated debt. If interest rate in the US increases, the debts increase in value and they become uncontrollable. In addition, as foreign interest rate increases, emerging economies will struggle to keep their assets attractive or limit the capital outflow movements. The situation can be worse in economies which rely primary on natural resources and commodities which are priced in the US dollar. Within a low inflation framework, economies may suffer from high interest rates that led to increase the level of capital inflows which appreciates their exchange rates and consequently the domestic prices. All these bad consequences diminish the effectiveness of monetary policy and undermine the control over a low inflation strategy.

Even with partial degree of dollarization, dollarization presents a challenge for the full-fledged IT, and thereby the advantages of framework will be limited. But what drives domestic financial dollarization?

The financial dollarization may exist as a result of low quality currencies, or long-lasting inflationary memories and the time inconsistency problem [38]. In addition, fear of floating [48], or vulnerability to capital flight, sudden stops, and financial crisis [39] contribute to increasing the financial dollarization. The tendency towards the asymmetric exchange rate pass through, i.e., tendency towards currency depreciation can also be a reason [49].

Therefore, inflation targeters made huge efforts to elude the financial dollarization and alleviate its adverse impacts. This includes the adoption of inflation-indexed instruments; intensifying financial regulation to hedge the exposure of domestic firms and businesses; limitations imposed on Dollar deposits and the compulsory exchange from foreign to domestic currency; and the development of domestic

7 For more details, readers are referred to Levy-Yeyati (2003) currency instruments to act as substitutes for foreign currency instruments. [38] discussed the main ingredients of a "carrotand-stick" dedollarization strategy; "the stick" includes measures to reduce dollarization motives, while "the carrot" considers the development of local currency markets. Indeed, the dollarization of deposits as well as transactions dollarization rapidly declined in many Latin American ITers [26].

However, it is believed that such de-dollarization policies can have adverse impacts on the economies which are prone to capital flight $[38,34,57]$. In indebted countries such strict regulation may increase offshorization, i.e. it can stimulate capital flights towards offshore heavens.

In addition, during and after the 2007 financial crisis, researchers started to argue that some external factors have helped developing countries with their efforts in adopting IT and gaining from disinflation polices; this includes low world interest rates during the time before the financial crisis. On the other hand, some economists think that what helped developing countries with IT was the implementation of domestic policies that limited the freedom of government and this consequently lowered the budget deficit which helped lowering inflationary pressures and foreign loans.

[43] revealed that de-dollarization polices that started after 2001 in Turkey with the shift towards IT has lost its progress after May 2006. So the authors could not conclude whether Turkey changed the direction of dollarization to dedollarization. Further, [14] who examined the dedollarization in inflation targeting emerging market countries found that global factors have helped countries in their dedollarization policies during the early 2000 s to the 2008 financial crisis. However, they noted that dedollarization has reversed or postponed in many countries after the financial crisis suggesting the interaction between domestic and global factors and that inflation targeters might still be vulnerable to world shocks especially at bad times. ${ }^{8}$ [11] argued that investors may develop a currency trust when they become confident that currency movements would not expropriate their investment in assets denominated in local currency. This confidence entails that the central bank holds enough control not to allow random shocks to prevail, and this in particular is linked to the concept of inflation credibility. That is why the present paper explores whether developing full-fledged ITers and after years of executing disinflation and dedollarization polices have generated currency trust among the market agents.

\section{Data Sources}

We construct a balanced panel data of eight full-fledged inflation targeting countries: Brazil, Chile, Columbia, Hungary, Indonesia, Mexico, Peru, Poland, for the quarterly period from the first quarter 2007 to the second quarter of 2019. The main source of data is the IMF/IFS database along

8 According to the BIS, estimates of the total US credit to non bank borrowers residing outside the US grew rapidly after the 2007 financial crisis. 
with central banks and the CEIC databases, namely for data on inflation targets. For the control group, we construct an unbalanced panel -very few data missing for one variable in an economy- of eight countries: Egypt, China, Morocco, India, Jordan, Saudi Arabia, Qatar, Nigeria and the data were extracted from the IMF/IFS and the countries' central banks (Qatar, Nigeria, Egypt, Jordan) and the CEIC database (Morocco, Saudi Arabia) and St. Louis Fred.

\section{Methodology}

To achieve our objectives, a linear panel model is constructed which considers the response of local policy interest rate to world policy interest rate (monetary shock) and the main objectives of monetary policy that minimize the central bank's loss function. Policy makers' optimization problem here is to minimize a loss function that includes deviation of inflation rate from its target and deviation of GDP from potential output represented as follows:

$$
L=\left(P_{t}-P^{*}\right)^{2}+\lambda\left(y-y^{*}\right)^{2} \lambda>0
$$

Optimality of the panel model that examines the response to world interest rates implies a Taylor rule of the following equation:

$$
\begin{gathered}
{\left[r^{d}=r^{w}+\beta_{1}\left(P_{i t}-P_{i t}{ }^{*}\right)+\beta_{2}\left(y_{i t}-y_{i t}{ }^{*}\right){ }_{+} U_{i t}\right] \operatorname{ITT}(1)} \\
{\left[U_{i t}=\alpha_{i}+\epsilon_{i t}\right] \mathrm{IT}}
\end{gathered}
$$

Where $r^{d}$ represents the policy interest rate in inflation targeting economies. $r^{w}$ is the world (US) policy interest rate (the fed rate). $\left(P_{i t}-P_{i t}{ }^{*}\right)$ is $1 \times k$ vector of the deviation of inflation rate from its predetermined target. $\left(y_{i t}-y_{i t}{ }^{*}\right)$ is $1 \times k$ vector of the deviation of GDP from potential output. The univariate Hodrick-Prescott filter is applied to extract the trend output from GDP data to estimate the potential output. $\beta_{1}$ and $\beta_{2}$ are the $k \times 1$ vector of coefficient on the exogenous variables. The composite error $\left(\mathrm{U}_{\mathrm{it}}\right)$ includes both $\alpha_{i}$ and $\varepsilon_{i t}$ which the former is the random country-specific estimator and the later denotes idiosyncratic disturbances. All monetary shocks are given equal weight, that is the probability of upward movements $(\mathrm{w}=1 / 4)$ equals the probability of downward movements $(\mathrm{w}=1 / 4)$ in domestic interest rates to world interest rates and both probabilities equal the probability of no movements $(w=1 / 2)$. For flexible IT, the country has a flexible inflation targeting with a positive weight on output stabilization thereby the conditional forecasts of inflation adjust gradually towards the inflation target [55]. We examine whether there are significant movements in interest rate to world shocks and whether that response is low compared to non ITers, i.e. strict exchange rate targeters and other regimes with managed exchange rate regimes (fear of floating). The panel linear models for the control group can be presented as follows:

$$
\begin{gathered}
{\left[r^{d}=r^{w}+\beta_{1}\left(P_{i t}-P_{i t}^{*}\right)+\beta_{2}\left(y_{i t}-y_{i t}{ }^{*}\right){ }_{+} U_{i t}\right] \text { control }} \\
{\left[U_{i t}=\alpha_{i}+\epsilon_{i t}\right] \text { control }}
\end{gathered}
$$

Where $r^{d}$ represents the policy interest rate in the control group. $r^{w}$ is the world (US) policy interest rate. $\left(P_{i t}-P_{i t}{ }^{*}\right)$ is $1 \times k$ vector of the deviation of inflation rate from it the inflation rate in the US. $\left(y_{i t}-y_{i t}{ }^{*}\right)$ is $1 \times k$ vector of the deviation of GDP from potential output. The univariate Hodrick-Prescott filter is applied to extract the trend output from GDP data to estimate the potential output. $\beta_{1}$ and $\beta_{2}$ are the $k \times 1$ vector of coefficient on the exogenous variables. The composite error $\left(\mathrm{U}_{\mathrm{it}}\right)$ includes both $\alpha_{i}$ and $\varepsilon_{i t}$ which the former is the random country-specific estimator and the later denotes idiosyncratic errors. ${ }^{9}$

Under IT, price stability is the main and ultimate goal for monetary Policy; thereby countries may follow a strict inflation targeting regime that is economies place a zero weight on output stabilization. This indicates that the central bank responds and directs its instruments so that the inflation forecast equals the target. For developing countries, we cannot infer a priori whether the ITers follow a strict IT regime and have only one objective or have some flexibility to consider other objectives such as the output stabilization. $[41,55]$ and [1] found that inflation targeters are flexible as they aim to lower inflation volatility as well as output volatility. [31] suggests that many ITers reflect fear of floating and they intervene for output reasons. Therefore, we first follow this possible scenario but we then assume that the countries place zero weight on deviation of GDP from potential output.

Most literature on IT suggests that policy makers should consider the role played by the exchange rate fluctuations upon inflation and output gap but should not consider an independent role for the exchange rate stabilization. We note here that a full-fledged inflation targeter follows a flexible exchange rate regime so they should place zero weight on exchange rate stabilization.

The problem that arises in dealing with panels is the heterogeneity across cross-sections. To eliminate the country unobserved heterogeneity in stationary panels, we estimate the linear model by the fixed effects (within estimator) and random effects where the latter presumes that specific cross heterogeneity is orthogonal to regressors. The within estimator helps in controlling the omitted bias resulted from time constant unobserved heterogeneity and presumes that the individual-specific effects are correlated with the regressors. The specification test of Hausman is run to select the optimal estimator (the fixed or random effects) under the null that cross sections have correlated effects.

[59] is used to test for autocorrelation in the idiosyncratic errors of the linear panel model and detect the existence of first order serially correlated errors under the null of no serial correlation in the residuals. In addition, we test for groupwise homoskedasticity in the variances of countries heterogeneity in balanced/unbalanced long panels by the mean of modified Wald test for groupwise heteroskedasticity

9 For the control group the probability of no movements in interest rate is assumed zero. Similar models are widely used in the literature to examine the interest rate and exchange rate pass through channels. 
test under the null of homoskedasticity. Furthermore, we test for the possible contemporaneous correlations across countries by performing the cross-sectional dependence test of Pesaran [46] with statistic follows a standard normal distribution. The test implements the correlation-coefficients between the time-series for each macro panel group data and can handle both balanced and unbalanced panels.

If the idiosyncratic errors are found autocorrelated, heteroskedatic and spatially dependent, the [20] spatial correlation standard errors is employed to correct for autocorrelation, heterskedasticity and dependence across individuals. The maximum lag order for autocorrelation is set by the default plug-in procedures, $\mathrm{m}(\mathrm{T})=$ floor $\left[4(\mathrm{~T} / 100)^{\wedge}(2 / 9)\right]$ where $\mathrm{T}$ is the number of time dimension.

\section{Results}

Our goal is to assess the sensitivity of policy interest in developing countries under the IT regime to movements in the world monetary shocks compared to that in developing economies under other regimes (the control group).

We start by examining whether the long panels exhibit a unit root process. Levin, Lin, and Chu (LLC) test is utilized to test for a common unit root process across countries. The test employs a null hypothesis of a unit root. An individual constant is included and the number of lags is specified by the Akaike information criterion. The null hypothesis of nonstationary at level is rejected for all the panel variables with high level of significance. The results of the LLC test are presented in Table 1.

The fixed effect is then used to estimate the linear models. For the main and control groups alike, the cross-section heterogeneity is found significant as the probability of Fstatistic reported in the results Tables 2 and 3 indicates the rejection of the null hypothesis of no country heterogeneity implying that the estimation by pooled OLS is inefficient. Furthermore, the Woodridge test and the modified LM test provide evidence that the errors are autocorrelated and heteroskedatic, respectively. The Pesaran cross-sectional dependence test suggests that in all cases we cannot assume countries spatial independence. Hence, the results obtained from the fixed effect with a default standard error are inefficient and thus the inferences are incorrect. To correct for this, we apply the Driscol and Kraay standard errors, and the results are reported in the second column of Tables 2 and 3 for the main IT group and control group, respectively. In all models, the Hausman specification test is estimated and provides evidence that the non random estimator is more consistent than random effect.

We first begin with the fully selected IT group and the control group. The findings, for the IT group presented in Table 2 show that the response of ITers' interest rate to foreign shocks is high and it is even higher than that to deviation of inflation rate from the announced target. However, in all models that place a weight on output stabilization, the output gap is found insignificant. According to the results obtained for the ITers reported in Table 2, a $1 \%$ raise in world monetary interest rate accounts for a $0.54 \%$ change in the ITers' interest rates. While the response of their interest rate to deviation of real inflation from the target is much smaller, i.e. around $0.12 \%$. When we assume a strict IT behavior and assign zero weight to deviation of GDP from potential output, the results remained robust, see the third and fourth column of Table 2

Surprisingly, the interest rate of the control group was less responsive to the world monetary shocks compared to the ITers' with a response of $0.44 \%$. The inflation differential is found significant but its influence on domestic interest rates is weak. The results for the control group reported in Table 3 provide evidence that the response of ITers to foreign shocks is stronger compared to non-ITers. Nevertheless, the interest rate in control group is less sensitive to real inflation deviation from the target. Similar to the ITers, the deviation in output has no effect on the policy interest rate, and even when we assume zero weight on output stabilization, the findings remain robust.

For a robustness checking, each group is split into two sub-groups. We first split the control group into two subpanels: economies under the de jure and de facto Fixed Exchange Rate Targeting (FERT) to the US Dollar and the second group: economies with other monetary regimes and a managed exchange rate system. In all sub panel cases, the Driscoll and Kraay's standard deviation is implemented to correct for strong and weak spatial dependence as well as for autocorrelated and heteroskedatic errors. The Hausman test confirms that the country-specific effects are correlated with the independent variables. ${ }^{10}$

When we split the control panel sample into two subpanels, the findings reveal that the response of FERT economies to world shocks is the highest. Expectedly, economies under the fixed exchange rate rule do not have any room of monetary policy to respond to domestic goals, and that inflation might not be well-anchored as the regime promises. Indeed, the FERT countries appear to have the lowest independence with respect to responding to domestic objectives; as inflation differential does not generate any changing effects on the policy rate as can be seen from Table 4.

Interestingly, the control panel including countries with regimes other than FERT and IT has a different story here. Although such countries have previously abandoned the FERT regime and they currently follow a managed exchange rate with a nominal anchor, the results, presented in Table 5 indicate that their interest rate does not respond to foreign shocks and that they enjoy some flexibility in responding to deviation of inflation rate from the target (the US inflation); the response that we supposed to exist in the FERT countries.

In addition, we split the ITers group: the first group contains the South American Countries while the second

10 Even when the cross-sectional independence could not be rejected at a high level of significance, the standard error resolves the problems of autocorrelation and heterskedasticity. 
includes the European countries with Indonesia. In all sub panel cases, the Driscoll and Kraay's standard deviation is employed as autocorrelation, heterskedasticity and spatial dependence problems present in the data.

The findings derived from the first panel -the Latin American economies- suggest that the response to world shocks is high but it is lower than that found for the FERT countries. Policy interest rate reaction to deviation from inflation is found significant but in all cases, this response is found weaker than that to the foreign shocks, as can be seen from Table 6. This finding calls into question the way ITers prioritize their goals or create their own monetary policies. The world monetary shocks positively impact the policy interest rates of the ITers in the Latin America, as the change in the US fed rate by $1 \%$ changes local interest rates by roughly $0.46 \%$. Further, if inflation is deviated from target by $1 \%$, the policy rate in these economies responds by a raise of $0.20 \%$.

Surprisingly, the second panel that includes only the European countries with Indonesia has the highest vulnerability to external monetary shocks compared to all subsamples. And contrary to expectations, the response of interest rate to deviation of inflation form target is found insignificant. The results derived from this IT group panel unexpectedly show that an increase of one percent in the US interest rate lead to positive change of $0.74 \%$ in domestic policy interest rates, as shown in Table 7, on the other hand, the deviation of inflation from target has no significant impact on local interest rate, which undoubtedly poses many questions for the implementation of IT in developing countries. The results in all subsamples are found robust even when we assume a zero weight on output stabilization.

When we assumed policy inertia, and generated a oneperiod lead policy interest rate, the results remained nearly similar; the response to external shocks and inflation differential slightly increased. To save space, the results of policy inertia are not reported but they are available from the author upon request.

\section{Conclusions}

This paper comes to question the role of adopting a fullfledged inflation targeting in developing countries by examining the response of local interest rates to monetary world shocks. Countries under inflation targeting should enjoy high levels of central bank independence, transparency and effective monetary policy instruments as well as exchange rate flexibility. Many countries during the early years after adopting the framework has improved the framework requirements and shifted from lite or eclectic inflation targeting to the full-fledged one. In most developing countries, these efforts come in tandem with de-dollarization policies in order to lower the vulnerability to foreign shocks and any related crises. Therefore, the paper examines the response of the main monetary instrument in developing countries with inflation targeting to world monetary shocks after years of building the credibility of the framework and moving to the full-fledged form and conducting macroprudential polices. However, the period of analysis also cover the time during and after the 2008 financial crisis which can be considered a bad time for all economies. Hence, from a regime evaluation perspective, we compare the response to world monetary shocks in inflation targeters to that in developing economies with other monetary regimes. Estimating linear panel Taylor rule based models by the fixed effects; the results show that policy interest rates in inflation targeting countries are more vulnerable and sensitive to world monetary shocks compared to the control group of countries. In addition, the response of ITers interest rate to monetary shocks is higher than their reaction to the deviation of inflation from target. After splitting the panel sample groups into subsamples, it appears that inflation targeters do not enjoy flexibility in responding to world monetary shocks compared to non ITers. Instead, the control panel with managed exchange rate monetary regimes (e.g fixed to a basket, monetary targeting) have the lowest vulnerability to external monetary shocks.

The significant and strong co-movement of local and foreign interest rate for inflation targeting might reflect that the cycle business at home and abroad requires similar monetary policy reaction [23]. Further, the central bank might choose not to pursue a different monetary policy and concerns about the financial structure and terms of trade shocks. Indeed, the economic independence of monetary policy has a problem concerning the incentive to the delegation of monetary policy to act in the interest of the government and the people [10]. However, if full-fledged IT conditions truly exist in developing countries, the inflation targeters could not benefit or choose not benefit from it. Here we could claim that the strong co-movements between the local and world monetary instruments may explain why most developing countries missed their inflation targets. The question that should be raised is whether price stability is the ultimate goal of monetary policy in developing countries.

We can also argue that the response does not always depend on the regime but on the conditions of the time period in question. That is why inflation targeting itself as a framework for monetary policy does not alone support the overall performance and independence of monetary policy especially during bad times and recovery from international crises. However, more investigation is needed to study the exchange rate vulnerability and policies to support currencies trust and the effect of shocks and news in the Forex market under the framework namely for developing countries.

Table 1. Panel Unit Root.

\begin{tabular}{ll}
\hline Panel & Level (LLC test-statistics) \\
\hline $\mathrm{i}^{\mathrm{w}}$ & $-8.72^{* * *}$ \\
$\mathrm{I}^{\mathrm{d}}$ (ITers) & $-2.08^{* *}$ \\
$\mathrm{p}-\mathrm{p}^{*}$ (ITers) & $-12.22 * * *$ \\
$\mathrm{y}-\mathrm{y} *$ (ITers) & $-4.47 * * *$ \\
$\mathrm{Id}$ (control) & $-2.59 * * *$ \\
$\mathrm{p}-\mathrm{p}^{*}$ (control) & $-9.26 * * *$ \\
$\mathrm{y}-\mathrm{y} *$ (control) & $-10.70^{* * *}$ \\
\hline
\end{tabular}

Note: $* * *, * *, *$ denote significance at $1 \%, 5 \%$ and $10 \%$, respectively. 
Table 2 Fixed Effects Estimation for Inflation Targeters (full group).

\begin{tabular}{|c|c|c|c|c|}
\hline & (1) & D-K & Zero stabilization & D-K \\
\hline$\alpha$ & $\begin{array}{l}6.320^{* * *} \\
(0.190)\end{array}$ & $\begin{array}{l}6.323 * * * \\
(0.452)\end{array}$ & $\begin{array}{l}6.336^{* * *} \\
(0.189)\end{array}$ & $\begin{array}{l}6.336 * * * \\
(0.468)\end{array}$ \\
\hline$i^{d}$ & $\begin{array}{l}0.539 * * * \\
(0.099)\end{array}$ & $\begin{array}{l}0.539^{* *} \\
(0.232)\end{array}$ & $\begin{array}{l}0.526 * * * \\
(0.098)\end{array}$ & $\begin{array}{l}0.526^{*} \\
(0.255)\end{array}$ \\
\hline$\left(p-p^{*}\right)$ & $\begin{array}{l}0.120 * * * \\
(0.031)\end{array}$ & $\begin{array}{l}0.120 * * * \\
(0.037)\end{array}$ & $\begin{array}{l}0.123 * * * \\
(0.031)\end{array}$ & $\begin{array}{l}0.123 * * * \\
(0.035)\end{array}$ \\
\hline$\left(y-y^{*}\right)$ & $\begin{array}{l}-1.046 \\
(1.321)\end{array}$ & $\begin{array}{l}-1.046 \\
(2.819)\end{array}$ & & \\
\hline Fixed effect, F-test & $\begin{array}{l}17.43 \\
{[0.000]}\end{array}$ & & $\begin{array}{l}25.85 \\
{[0.000]}\end{array}$ & \\
\hline Groupwise heterskedasticity, Chi2 (8) & $\begin{array}{l}1478.76 \\
{[0.000]}\end{array}$ & & $\begin{array}{l}1649.42 \\
{[0.000]}\end{array}$ & \\
\hline Woodridge Test & $\begin{array}{l}21.739 \\
{[0.001]}\end{array}$ & & $\begin{array}{l}21.739 \\
{[0.001]}\end{array}$ & \\
\hline Pesaran Cross Sectional Dependence stat. & $\begin{array}{l}10.47 \\
{[0.000]}\end{array}$ & & $\begin{array}{l}10.42 \\
{[0.000]}\end{array}$ & \\
\hline Hausman Test & {$[0.000]$} & & {$[0.000]$} & \\
\hline Lag length & & 4 & & 4 \\
\hline
\end{tabular}

Note: $* * * * *, *$ denote significance at $1 \%, 5 \%$ and $10 \%$, respectively. Standard errors are between parentheses. Probability is between brackets. The null hypothesis of cross sectional dependence test is that errors are cross sectional independence. D-K denotes Driscoll and Kraay standard errors. (1) refers to equation number (1). Zero Stabilization: zero weight placed on output stabilization.

Table 3. Fixed Effects Estimation for control group (full).

\begin{tabular}{|c|c|c|c|c|}
\hline & (2) & D-K & Zero stabilization & D-K \\
\hline$\alpha$ & $\begin{array}{l}4.835 * * * \\
(0.136)\end{array}$ & $\begin{array}{l}4.835 * * * \\
(0.230)\end{array}$ & $\begin{array}{l}4.878^{* * *} \\
(0.136)\end{array}$ & $\begin{array}{l}4.848 * * * \\
(0.207)\end{array}$ \\
\hline$i^{\mathrm{d}}$ & $\begin{array}{l}0.435^{* * *} \\
(0.067)\end{array}$ & $\begin{array}{l}0.435 * * \\
(0.165)\end{array}$ & $\begin{array}{l}0.426 * * * \\
(0.067)\end{array}$ & $\begin{array}{l}0.426^{* *} \\
(0.149)\end{array}$ \\
\hline$\left(\mathrm{p}-\mathrm{p}^{*}\right)$ & $\begin{array}{l}0.038^{* * *} \\
(0.013)\end{array}$ & $\begin{array}{l}0.038^{*} \\
(0.013)\end{array}$ & $\begin{array}{l}0.037 * * * \\
(0.013)\end{array}$ & $\begin{array}{l}0.037^{*} \\
(0.019)\end{array}$ \\
\hline$\left(y-y^{*}\right)$ & $\begin{array}{l}-1.356 \\
(0.879)\end{array}$ & $\begin{array}{l}-1.356 \\
(2.306)\end{array}$ & & \\
\hline Fixed effect, F-test & $\begin{array}{l}16.15 \\
{[0.000]}\end{array}$ & & $\begin{array}{l}22.44 \\
{[0.000]}\end{array}$ & \\
\hline Groupwise heterskedasticity, Chi2 (8) & $\begin{array}{l}2194.71 \\
{[0.000]}\end{array}$ & & $\begin{array}{l}2533.23 \\
{[0.000]}\end{array}$ & \\
\hline Woodridge Test & $\begin{array}{l}62.515 \\
{[0.000]}\end{array}$ & & $\begin{array}{l}90.387 \\
{[0.000]}\end{array}$ & \\
\hline Pesaran Cross Sectional Dependence stat. & $\begin{array}{l}2.33 \\
{[0.000]}\end{array}$ & & $\begin{array}{l}2.59 \\
{[0.010]}\end{array}$ & \\
\hline Hausman Test & {$[0.000]$} & & {$[0.000]$} & \\
\hline
\end{tabular}

Note: $* * *, * * *$ denote significance at $1 \%, 5 \%$ and $10 \%$, respectively. Standard errors are between parentheses. Probability is between brackets. The null hypothesis of cross sectional dependence test is that errors are cross sectional independence. D-K denotes Driscoll and Kraay standard errors. (2) refers to equation number (2). Zero Stabilization: zero weight placed on output stabilization.

Table 4. Fixed Effects Estimation for control group only FERT economies.

\begin{tabular}{lllll}
\hline & $(\mathbf{1})$ & D-K & Zero stabilization & D-K \\
\hline$\alpha$ & $2.067^{* * *}$ & $2.067^{* * *}$ & $2.063^{* * *}$ & $2.063^{* * *}$ \\
& $(0.078)$ & $(0.131)$ & $(0.078)$ & $(0.129)$ \\
$\mathrm{i}^{\mathrm{d}}$ & $0.687^{* * *}$ & $0.687^{* * *}$ & $0.691^{* * *}$ & $0.690^{* * *}$ \\
& $(0.040)$ & $(0.050)$ & $(0.040)$ & $(0.050)$ \\
$\left(\mathrm{p}-\mathrm{p}^{*}\right)$ & -0.006 & -0.006 & -0.004 & -0.004 \\
& $(0.008)$ & $(0.009)$ & $(0.008)$ & $(0.008)$ \\
$\left(\mathrm{y}-\mathrm{y}^{*}\right)$ & 0.575 & 0.575 & \\
& $(0.533)$ & $(0.862)$ & & \\
Fixed effect, F-test & $\mathrm{F}(3,189)=449.63$ & & $\mathrm{~F}(3,190)=452.47$ \\
& {$[0.000]$} & & {$[0.000]$} & 38.5 \\
Groupwise heterskedasticity, Chi2 (4) & 29.07 & & {$[0.000]$} \\
& {$[0.000]$} & & 308.232 \\
Woodridge Test & 285.053 & {$[0.000]$} \\
Pesaran Cross Sectional Dependence stat. & {$[0.000]$} & & 1.61 \\
\hline
\end{tabular}




\begin{tabular}{|c|c|c|c|c|}
\hline & (1) & D-K & Zero stabilization & D-K \\
\hline Hausman Test & $\begin{array}{l}{[0.151]} \\
{[0.000]}\end{array}$ & & $\begin{array}{l}{[0.107]} \\
{[0.000]}\end{array}$ & \\
\hline
\end{tabular}

Note: $* * *, * * *$ denote significance at $1 \%, 5 \%$ and $10 \%$, respectively. Standard errors are between parentheses. Probability is between brackets. The null hypothesis of cross sectional dependence test is that errors are cross sectional independence. D-K denotes Driscoll and Kraay standard errors. (1) refers to equation number (1). Zero Stabilization: zero weight placed on output stabilization.

Table 5. Fixed Effects Estimation for control group other regimes than the FERT.

\begin{tabular}{lllll}
\hline & $(2)$ & D-K & Zero stabilization & D-K \\
\hline$\alpha$ & $7.570^{* * *}$ & $7.570^{* * *}$ & $7.513^{* * *}$ & $7.513^{* * *}$ \\
& $(0.275)$ & $(0.548)$ & $(0.273)$ & $0.504)$ \\
$\mathrm{i}^{\mathrm{d}}$ & 0.189 & 0.189 & 0.189 & $(189$ \\
& $(0.127)$ & $(0.363)$ & $(0.126)$ & $(0.337)$ \\
$\left(\mathrm{p}-\mathrm{p}^{*}\right)$ & $0.061^{* *}$ & $0.061^{*}$ & $0.069^{* * *}$ & 0.069 \\
& $(0.026)$ & $(0.021)$ & $(0.025)$ & $(0.032)$ \\
$\left(\mathrm{y}-\mathrm{y}^{*}\right)$ & -2.682 & -2.682 & -2.682 & $(1.702)$ \\
& $(1.702)$ & $(4.431)$ & $\mathrm{F}(3,190)=136.81$ \\
Fixed effect, F-test & $\mathrm{F}(3,187)=136.63$ & & {$[0.000]$} \\
& {$[0.000]$} & & 13711.87 \\
Groupwise heterskedasticity, Chi2 (4) & 12961.57 & & {$[0.000]$} \\
& {$[0.000]$} & & 42.736 \\
Woodridge Test & 26.050 & & {$[0.000]$} \\
& {$[0.014]$} & & 1.90 \\
Pesaran Cross Sectional Dependence stat. & 2.13 & {$[0.151]$} \\
Hausman Test & {$[0.033]$} & & {$[0.060]$} \\
\hline
\end{tabular}

Note: $* * *, * * *$ denote significance at $1 \%, 5 \%$ and $10 \%$, respectively. Standard errors are between parentheses. Probability is between brackets. The null hypothesis of cross sectional dependence test is that errors are cross sectional independence. D-K denotes Driscoll and Kraay standard errors. (2) refers to equation number (2). Zero Stabilization: zero weight placed on output stabilization.

Table 6. Fixed Effects Estimation for ITers (Latin American Countries).

\begin{tabular}{|c|c|c|c|c|}
\hline & (1) & D-K & Zero stabilization & D-K \\
\hline$\alpha$ & $\begin{array}{l}7.429 * * * \\
(0.213)\end{array}$ & $\begin{array}{l}7.429 * * * \\
(0.271)\end{array}$ & $\begin{array}{l}7.460 * * * \\
(0.212)\end{array}$ & $\begin{array}{l}7.460 * * * \\
(0.307)\end{array}$ \\
\hline$i^{\mathrm{d}}$ & $\begin{array}{l}0.456 * * * \\
(0.110)\end{array}$ & $\begin{array}{l}0.456^{*} \\
(0.157)\end{array}$ & $\begin{array}{l}0.425^{* * *} \\
(0.108)\end{array}$ & $\begin{array}{l}0.425^{*} \\
(0.041)\end{array}$ \\
\hline$\left(\mathrm{p}-\mathrm{p}^{*}\right)$ & $\begin{array}{l}0.203 * * * \\
(0.041)\end{array}$ & $\begin{array}{l}0.203^{* *} \\
(0.042)\end{array}$ & $\begin{array}{l}0.212 * * * \\
(0.040)\end{array}$ & $\begin{array}{l}0.212 * * \\
(0.041)\end{array}$ \\
\hline$\left(y-y^{*}\right)$ & $\begin{array}{l}-2.102 \\
(1.455)\end{array}$ & $\begin{array}{l}-2.102 \\
(1.861)\end{array}$ & & \\
\hline Fixed effect, F-test & $\begin{array}{l}\mathrm{F}(3,189)=460.00 \\
{[0.000]}\end{array}$ & & $\begin{array}{l}\mathrm{F}(3,190)=457.02 \\
{[0.000]}\end{array}$ & \\
\hline Groupwise heterskedasticity, Chi2 (4) & $\begin{array}{l}34.30 \\
{[0.000]}\end{array}$ & & $\begin{array}{l}36.06 \\
{[0.000]}\end{array}$ & \\
\hline Woodridge Test & $\begin{array}{l}92.442 \\
{[0.002]}\end{array}$ & & $\begin{array}{l}94.187 \\
{[0.002]}\end{array}$ & \\
\hline Pesaran Cross Sectional Dependence stat. & $\begin{array}{l}2.15 \\
{[0.032]}\end{array}$ & & $\begin{array}{l}2.37 \\
{[0.018]}\end{array}$ & \\
\hline Hausman Test & {$[0.000]$} & & {$[0.000]$} & \\
\hline
\end{tabular}

Note: $* * *, * * *$ denote significance at $1 \%, 5 \%$ and $10 \%$, respectively. Standard errors are between parentheses. Probability is between brackets. The null hypothesis of cross sectional dependence test is that errors are cross sectional independence. D-K denotes Driscoll and Kraay standard errors. (1) refers to equation number (1). Zero Stabilization: zero weight placed on output stabilization.

Table 7. Fixed Effects Estimation for ITers (European Countries and Indonesia).

\begin{tabular}{lllll}
\hline & $\mathbf{( 1 )}$ & D-K & Zero stabilization & D-K \\
\hline$\alpha$ & & & & \\
& $5.158^{* * *}$ & $5.158^{* * *}$ & $5.151^{* * *}$ & $5.151^{* * *}$ \\
$\mathrm{i}^{\mathrm{d}}$ & $(0.362)$ & $(0.629)$ & $(0.359)$ & $(0.650)$ \\
& $0.741^{* * *}$ & $0.741^{*}$ & $0.748^{* * *}$ & $0.748^{*}$ \\
$\left(\mathrm{p}-\mathrm{p}^{*}\right)$ & $(0.110)$ & $(0.273)$ & $(0.190)$ & $(0.304)$ \\
& 0.069 & 0.069 & 0.068 & 0.068 \\
$\left(\mathrm{y}-\mathrm{y}^{*}\right)$ & $(0.053)$ & $(0.067)$ & $(0.052)$ & $(0.064)$ \\
\hline
\end{tabular}




\begin{tabular}{|c|c|c|c|c|}
\hline & (1) & D-K & Zero stabilization & D-K \\
\hline & $(0.362)$ & $(5.548)$ & & \\
\hline \multirow[t]{2}{*}{ Fixed effect, F-test } & $F(3,189)=119.43$ & & $F(3,189)=120.71$ & \\
\hline & {$[0.000]$} & & {$[0.000]$} & \\
\hline \multirow[t]{2}{*}{ Groupwise heterskedasticity, Chi2 (4) } & 3361.57 & & 3086.51 & \\
\hline & {$[0.000]$} & & {$[0.000]$} & \\
\hline \multirow[t]{2}{*}{ Woodridge Test } & 77.158 & & 74.82 & \\
\hline & {$[0.003]$} & & {$[0.003]$} & \\
\hline \multirow[t]{2}{*}{ Pesaran Cross Sectional Dependence stat. } & 8.28 & & 8.48 & \\
\hline & {$[0.000]$} & & {$[0.000]$} & \\
\hline Hausman Test & {$[0.000]$} & & {$[0.000]$} & \\
\hline
\end{tabular}

Note: $* * * * *, *$ denote significance at $1 \%, 5 \%$ and $10 \%$, respectively. Standard errors are between parentheses. Probability is between brackets. The null hypothesis of cross sectional dependence test is that errors are cross sectional independence. D-K denotes Driscoll and Kraay standard errors. (1) refers to equation number (1). Zero Stabilization: zero weight placed on output stabilization.

\section{References}

[1] Agénor, P. R. (1999). Monetary policy under flexible exchange rates: an introduction to inflation targeting. Policy Research Working Papers. The World Bank.

[2] Albagli, E., \& Schmidt-Hebbel, K. (2003, March). By how much and why do inflation targeters miss their targets? In Conference on Monetary Policy and Learning.

[3] Aliyu, S. U. R., \& Englama, A. (2009). Is Nigeria ready for inflation targeting? MPRA Paper No. 14870

[4] Al-Marhubi, F. and T. D. Willett (1995). The anti inflationary influence of corporatist structures and central bank independence: The importance of the hump shaped hypothesis. Public Choice 84 (1-2), 153-162

[5] Alpanda, S., \& Honig, A. (2010). Political monetary cycles and a de facto ranking of central bank independence. Journal of International Money and Finance, 29 (6), 1003-1023.

[6] Ball, L. (1992). Why does high inflation raise inflation uncertainty? Journal of Monetary Economics 29 (3), 371-388.

[7] Ball, L. M. and N. Sheridan (2004). Does inflation targeting matter? In the inflation targeting debate, pp. 249-282. University of Chicago Press.

[8] Barro, R. J. and D. B. Gordon (1983). Rules, discretion and reputation in a model of monetary policy. Journal of monetary economics 12 (1), 101-121.

[9] Bernanke, B. S., T. Laubach, F. S. Mishkin, and A. S. Posen (1999). Inflation Targeting. Princenton University Press.

[10] Buiter, W. (2006, October). Rethinking inflation targeting and central bank independence. In Turkish Economic Association Conference, Ankara, September.

[11] Caballero, R. J., Cowan, K., \& Kearns, J. (2005). Fear of sudden stops: lessons from Australia and Chile. The Journal of Policy Reform, 8 (4), 313-354.

[12] Capistr'an, C. and M. Ramos-Francia (2010). Does inflation targeting affect the dispersion of inflation expectations? Journal of Money, Credit and Banking 42 (1), 113-134.

[13] Caselli, F. G., \& Roitman, A. (2019). Nonlinear exchangerate pass-through in emerging markets. International Finance, $22(3), 279-306$.
[14] Catão, M. L., \& Terrones, M. M. (2016). Financial dedollarization: A global perspective and the Peruvian experience. International Monetary Fund.

[15] Céspedes, L. F., Chang, R., \& Velasco, A. (2014). Is inflation targeting still on target? The recent experience of Latin America. International Finance, 17 (2), 185-208.

[16] Cukierman, A. and A. H. Meltzer (1986). A theory of ambiguity, credibility, and inflation under discretion and asymmetric information. Econometrica: Journal of the Econometric Society, 1099-1128.

[17] Cukierman, A., S. B. Web, and B. Neyapti (1992). Measuring the independence of central banks and its effect on policy outcomes. The World Bank Economic Review 6 (3), 353-398.

[18] De Haan, J. and W. J. Kooi (2000). Does central bank independence really matter?: New evidence for developing countries using a new indicator. Journal of Banking \& Finance 24 (4), 643-664.

[19] Drew, A. and "O. Karagedikli (2008). Some benefits of monetary policy transparency in new zealand. Technical report, Reserve Bank of New Zealand.

[20] Driscoll, J. C., \& Kraay, A. C. (1998). Consistent covariance matrix estimation with spatially dependent panel data. Review of economics and statistics, 80 (4), 549-560.

[21] Edwards, S. (2006). The relationship between exchange rates and inflation targeting revisited (No. w12163). National Bureau of Economic Research.

[22] Fernández-Arias, E., Yeyati, E. L., \& Morón, E. (2006). Financial Dollarization and Dedollarization [with Comments]. Economía, 6 (2), 37-100.

[23] Frankel, J., Schmukler, S. L., \& Serven, L. (2004). Global transmission of interest rates: monetary independence and currency regime. Journal of international Money and Finance, 23 (5), 701-733.

[24] Friedman, M. (1968). The role of monetary policy. The American Economic Review 58, 1-17.

[25] Friedman, M. (1977). Nobel lecture: inflation and unemployment. The Journal of Political Economy, 451-472.

[26] Fountas, S. (2010). Inflation, inflation uncertainty and growth: Are they related? Economic Modelling 27 (5), 896-899.

[27] Galindo, A. J., \& Leiderman, L. (2005). Living with Dollarization and the Route to Dedollarization. Inter- 
American Development Bank Working Paper.

[28] Garcia-Escribano, M. M. (2010). Peru: Drivers of dedollarization (No. 10-169). International Monetary Fund.

[29] Grilli, V., D. Masciandaro, and G. Tabellini (1994). Political and monetary institutions and public financial policies in the industrial countries. Monetary and Fiscal Policy 2, 179-226.

[30] Hess, G., \& Morris, C. S. (1996). The long-run costs of moderate inflation.Economic Review, Federal Reserve Bank of KansasCity, Second Quarter, 81, 71-88.

[31] Ho, C., \& McCauley, R. N. (2003). Living with flexible exchange rates: issues and recent experience in inflation targeting emerging market economies. BIS working paper no. 130 .

[32] Hochreiter, E., Schmidt-Hebbel, K., \& Winckler, G. (2002). Monetary Union: European Lessons, Latin American Prospects. The North American Journal of Economics and Finance, 13 (3), 297-321.

[33] Holub, T., \& Hurník, J. (2008). Ten years of Czech inflation targeting: missed targets and anchored expectations. Emerging Markets Finance and Trade, 44 (6), 67-86.

[34] Im, T. N., Dabadie, M., \& Sokha, N. (2007). Dollarization in Cambodia. National Bank of Cambodia.

[35] Judson, R., \& Orphanides, A. (1996). Inflation, Volatility, and Growth, Finance and Economics. Board of Governors, Federal Reserve of United States, Washington, DC, Discussion Paper, (96-19).

[36] Keskek, S. and M. Orhan (2010). Inflation and inflation uncertainty in turkey. Applied Economics 42 (10), 1281-1291.

[37] Kydland, F. E. and E. C. Prescott (1977). Rules rather than discretion: The inconsistency of optimal plans. The Journal of Political Economy, 473-491.

[38] Levy-Yeyati, E. L. (2003). Financial dedollarization: a carrot and stick approach. Available at SSRN 412369.

[39] Levy-Yeyati, E. L. (2006). Financial dollarization: evaluating the consequences. Economic Policy, 21 (45), 62-118.

[40] Lin, H.-Y. and H.-P. Chu (2013). Are fiscal deficits inflationary? Journal of International Money and Finance 32, 214-233.

[41] Loayza, O., \& Soto, R. (2002). Inflation targeting: design, performance, challenges. Banco Central de Chile.

[42] Mathew, J. T. (2003). Measuring central bank independence in twenty-five countries: A new index of institutional quality.

[43] Metin-Özcan, K., \& Us, V. (2007). Dedollarization in Turkey after decades of dollarization: A myth or reality? Physica A: Statistical Mechanics and its Applications, 385 (1), 292-306.

[44] Mishkin, F. S., \& Schmidt-Hebbel, K. (2007). Does inflation targeting make a difference? (No. w12876). National Bureau of Economic Research.

[45] Neumann, M. J. and J. Von Hagen (2002). Does inflation targeting matter? Technical report, ZEI working paper.

[46] Pesaran, M. (2004). General diagnostic tests for cross section dependence in panels. CESifo Working Paper, No. 1229.

[47] Phelps, E. S. (1968). Money-wage dynamics and labor-market equilibrium. The Journal of Political Economy, 678-711.

[48] Reinhart, C. M., Rogoff, K. S., \& Savastano, M. A. (2003). Addicted to dollars (No. w10015). National Bureau of Economic Research.

[49] Rennhack R, Nozaki M (2006): Financial dollarization in Latin America. IMF Working Paper, no. 7.

[50] Roger, M. S., \& Stone, M. M. R. (2005). On target? The international experience with achieving inflation targets (No. 5-163). International Monetary Fund.

[51] Schaechter, A., M. R. Stone, and M. Zelmer (2000). Adopting inflation targeting: Practical issues for emerging market countries, Volume 202. International monetary fund Washington, DC.

[52] Schmidt-Hebbel, K., \& Tapia, M. (2002). Monetary policy implementation and results in twenty inflation-targeting countries (Vol. 166). Banco Central de Chile.

[53] Siklos, P. L. (2008). No single definition of central bank independence is right for all countries. European Journal of Political Economy 24 (4), 802-816.

[54] Svensson, L. E. (1999). Inflation targeting as a monetary policy rule. Journal of Monetary Economics, 43 (3), 607-654.

[55] Svensson, L. E. (2000). Open-economy inflation targeting. Journal of International Economics, 50 (1), 155-183.

[56] Thornton, J. (2007). The relationship between inflation and inflation uncertainty in emerging market economies. Southern Economic Journal, 858-870.

[57] Vernengo, M., \& Bradbury, M. (2011). The limits to dollarization in Ecuador: Lessons from Argentina. Journal of World-Systems Research, 17 (2), 457-462.

[58] Walsh, C. E. (2009). Inflation targeting: What have we learned? International Finance 12 (2), 195-233.

[59] Wooldridge, J. M. (2002). Econometric Analysis of Cross Section and Panel Data. Cambridge, MA: MIT Press. 